\title{
Response of southern North Island hill pasture to nitrogen, molybdenum and lime
}

ZHOU JIAYOU', I. VALENTINE and J. HODGSON

Department of Plant Science, Massey University, Palmerstan North

\begin{abstract}
An experiment was designed to measure the effect of molybdenum (M), lime and nitrogen on steep $\left(>30^{\circ}\right)$ north-facing hill pasture on the Massey University Hill Farm, "Tuapaka". Treatments included application of molybdenum, lime (L), nitrogen $(\mathrm{N})$ alone and together with $\mathrm{Mb}$ and lime. $\mathrm{Mb}$ and lime werre applied in mid May at $0.05 \mathrm{~kg} /$ ha and $2000 \mathrm{~kg} / \mathrm{ha}$ separately, and $\mathrm{N}$ fertiliser was applied as urea in August and October at 60 and $20 \mathrm{~kg} \mathrm{~N} /$ ha respectively. Herbage and soil responses were measured over spring and summer 1992/93. Nitrogen fertiliser increased herbage mass accumulation from 3 to $41 \mathrm{~kg} \mathrm{DM} / \mathrm{kg} \mathrm{N}$ applied, and the response was increased by the addition of lime or MO. Ryegrass content increased in the sward and the low-fertility-tolerant grass species content decreased. Mb application increased the white clover content in the sward and subsequently resulted in the increase in herbage mass accumulation by $0.4 \%$ to $32 \%$. The effect of $\mathrm{Mb}$ application was larger than that of liming but less than that of $\mathrm{N}$ alone application. Liming increased soil pH by $0.24-0.3 \mathrm{pH}$ units per $2000 \mathrm{~kg}$ lime applied and soil moisture was increased from $2 \%$ to $26 \%$ over spring/summer, and the potential mineral nitrogen was increased by $94 \%$ in November. These resulted in the increase in herbage mass accumulation from $4.4 \%$ to $15 \%$. These results indicate that $\mathrm{Mb}$ and lime applications would be beneficial on these hill soils.
\end{abstract}

K eywords: herbage mass accumulation, hill country, lime, molybdenum, nitrogen, Trifolium repens

\section{Introduction}

The key to pasture improvement in hill country is the introduction of high producing legumes after the correction of soil nutrient deficiencies (White 1990). The corrections of low soil $\mathrm{pH}$ and deficiency of molybdenum (Mo) are considered to be a very important

1 Present address: Department of Animal and Veterinary Science, Southwest Minority Nationality College, Chengdu, China. steps for the establishment of improved pasture with high producing legumes in hill country (During 1972 1984; Edmeades 1984). It is generally agreed that Mo is critical for legumes and its application stimulates the legume growth and increases legume nitrogen $(\mathrm{N})$ fixation (Scott 1963; During 1984). On the other hand, the use of lime has an effect on the physical properties of the hill soil as well as increasing soil $\mathbf{p H}$ and the availability of Mo (During 1962; Edmeades 1984). The steady input of $\mathrm{N}$ is necessary for maintaining more productive grass species in hill country as the spring flush of mineralised nitrogen is short-lived (Ball 1982; Luscombe 1979). The practical experience and research results suggested that an application of Mo, lime and a tactical application of is $\mathrm{N}$ a very effective way of increasing pasture productivity and improving soil properties in hill country in New Zealand when phosphorus (P) and sulphur (S) status is adequate (Edmeades 1984; During 1962, 1972, 1984; Luscombe 1979, 1981; Ball 1982). Information is available on the response of many hill soils to $\mathrm{N}$ (Luscombe 1979; Ball 1982), but there is a lack of quantitative information on the maintenance requirements for Mo and time for many hill soils and this makes it difficult to provide firm recommendations on their use. This paper reports some results from a field trial designed to examine the effects of lime, $\mathrm{Mo}$ and $\mathrm{N}$ on herbage production and soil characteristics in North Island hill country.

\section{$M$ aterials and methods}

Site

The experiment was located on a hill block of Tuapaka farm, Massey University, which lies south east of the Manawatu river extending up into the flanks of the Tararua range. The experimental site was on a hill sheep unit with a sunny north-west aspect and land slope of about $35-40^{\circ}$. A dry, warm summer and cool, wet spring is the main meteorological feature of this hill country. The soil is a Halcombe steepland soil which is associated with the yellow-grey earths (Pollock \& McLaughlin 1986) with a soil $\mathbf{p H}$ range of about 5.2-5.4. The main pasture species on the hill country are the low-fertility-tolerant species, such as browntop (Agrostis tenuis Sibth.), chewings fescue (Festuca rubra L. commutata Gaud.) and sweet vernal (Anthoxanthum odoratum). Ryegrass (Lolium perenne 
L.) and white clover (Trifolium repens L.) occur in the pastures but are not abundant. No fertiliser has been applied in recent years on this hill country. The trial site was opened from mid May to October because the herbage growth was slow and animal grazing was not intensive. However, in late October it was electric fenced to exclude animals.

\section{Experimental design and treatments}

A randomised complete block design was used, associated with 4 replications of 6 treatments. Plot size was $3 \mathrm{~m} \times 1.5 \mathrm{~m}$. Six treatments were: (1) $0-$ control, no fertiliser application; (2) $\mathrm{N}=$ nitrogen fertiliser applied in August $(60 \mathrm{~kg} \mathrm{~N} / \mathrm{ha})$ and October $(20 \mathrm{~kg} \mathrm{~N} /$ ha), 1992; (3) L - $2000 \mathrm{~kg} / \mathrm{ha}$ time applied in mid May, 1992; (4) Mo - $50 \mathrm{~g} / \mathrm{ha}$ molybdenum applied in mid May, 1992; (5) NMo - $50 \mathrm{~g} / \mathrm{ha}$ M applied in mid May, $\mathrm{N}$ applied in mid August $(60 \mathrm{~kg} / \mathrm{ha})$ and mid October (20 kg/ha), 1992; (6) $\mathrm{NL}$ - $2000 \mathrm{~kg} / \mathrm{ha}$ lime applied in mid May, $\mathrm{N}$ applied in mid August $(60 \mathrm{~kg} / \mathrm{ha})$ and mid October $(20 \mathrm{~kg} / \mathrm{ha})$. Urea $(46 \% \mathrm{~N})$, sodium molybdate (39\% Mo) and limestone $\left(72 \% \mathrm{CaCO}_{3}\right)$ were used separately as fertilisers. Nitrogen fertiliser and limestone were applied by hand broadcasting and sodium molybdate was dissolved in water and applied with hand spray.

\section{Measurements}

\section{(a) Herbage mass}

The accumulated herbage mass was measured monthly from mid September to January using electric shears to cut herbage to ground level within one randomly placed $0.25 \times 0.25 \mathrm{~m}^{2}$ quadrat per plot.

\section{(b) Botanical composition}

The botanical composition of all the plots was measured in July, November, December 1992 and January 1993 using a point quadrat. Only first needle contact was recorded as one point and 100 points were recorded on each plot. The percentage content of each species category was calculated based on its contribution to the total 100 points.

\section{(c) Soil moisture (SM)}

The soil moisture was measured monthly using Time Domain Refractometer (TDR) at a depth of $20 \mathrm{~cm}$ (before November) and $15 \mathrm{~cm}$ (December onwards).

\section{(d) Soil $p H$}

Soil samples from individual plots were taken on May, October at a depth of $7.5 \mathrm{~cm}$. Soil samples were air dried and $\mathrm{pH}$ was measured in distilled water in 1:2.5 ratio (10 g soil:25 $\mathrm{ml}$ distilled water) using $\mathrm{pH}$ meter.

\section{(e) Soil mineral nitrogen}

Soils were sampled in November and a subsample was taken for aerobic incubation (for 14 days at $30^{\circ} \mathrm{C}$ ). Incubated and unincubated air-dry soil samples were extracted with a $0.1 \mathrm{M} \mathrm{KCl}$ solution and analysed for nitrate $\left(\mathrm{NO}_{3}{ }^{-}\right)$and ammonium $(\mathrm{NH},+)$ using an autoanalyser.

\section{Statistical analysis}

All data were initially analysed in accordance with the randomised complete block design of the experiment The analysis of variance (ANOVA) of data and the tests for significance of differences among treatments used the Repeated Measures option of the General Linear Model procedure of PC-SAS. The chi-square test was used to examine the significance of $\mathrm{N} \times \mathrm{L}$ and $\mathrm{N} \times \mathrm{Mo}$ interaction.

\section{Results and discussion}

\section{Response to $\mathbf{N}$ application}

Nitrogen application significantly increased the herbage mass over spring/summer (Table 1). Table 2 shows that the $\mathrm{N}$ response efficiency $(\mathrm{kg} \mathrm{DM} / \mathrm{kg} \mathrm{N}$ applied) varied from 3.5 to $41.4 \mathrm{~kg} \mathrm{DM} / \mathrm{kg} \mathrm{N}$ applied under different treatments (N, NMo and NL treatments). Addition of $\mathrm{Mo}$ and lime increased the $\mathrm{N}$ response efficiency. The response between $\mathrm{N}$ and lime was additive and there was a significant $\mathrm{N} \times \mathrm{L}$ interaction whereas the response to $\mathrm{N}$ and $\mathrm{Mo}$ application was not

Table 1 Herbage mass over time for the fertiliser treatments (kg DM/ha).

\begin{tabular}{lcccc}
\hline Treatments & September & November & December & January \\
\hline 0 & $780 \mathrm{a}$ & $1074 \mathrm{a}$ & $3435 \mathrm{a}$ & $\mathbf{7 1 6 9} \mathbf{a}$ \\
$\mathrm{N}$ & $987 \mathrm{ab}$ & $1472 \mathrm{bc}$ & $4230 \mathrm{~b}$ & $\mathbf{9 5 1 5} \mathrm{ab}$ \\
$\mathrm{L}$ & $824 \mathrm{ab}$ & $1121 \mathrm{ab}$ & $3949 \mathrm{ab}$ & $7900 \mathrm{ab}$ \\
Mo & $989 \mathrm{ab}$ & $1413 \mathrm{abc}$ & $\mathbf{3 9 1 7} \mathrm{ab}$ & $\mathbf{7 1 9 6 \mathrm { a }}$ \\
NMo & $978 \mathrm{ab}$ & $\mathbf{1 5 3 4} \mathrm{c}$ & $4351 \mathrm{~b}$ & $9963 \mathrm{ab}$ \\
$\mathrm{NL}$ & $\mathbf{1 1 4 7} \mathrm{b}$ & $\mathbf{1 5 5 3} \mathrm{c}$ & $5041 \mathrm{c}$ & $10481 \mathrm{~b}$ \\
SEM & 107 & 120 & 197 & 237 \\
F-test & & NS & & \\
\hline
\end{tabular}

Note: means with the same letter within each column are not significantly different $(P>0.05)$.

*: $P<0.05$ **: $P<0.010^{* *}: P<0.001$ NS: not significant

Table 2 The $\mathrm{N}$ response efficiencies on applied N (kg DM/kg $\mathrm{N}$ applied)

\begin{tabular}{lcccc}
\hline Treatment & September & November & December & January \\
\hline N & 3.5 & 5.0 & 9.9 & 29.3 \\
NMo & 3.3 & 5.8 & 11.5 & 34.9 \\
NL & 6.1 & 6.0 & 20.1 & 41.4 \\
\hline
\end{tabular}


Table 3 The seasonal botanical composition under different treatments (\% content in the sward on each month)

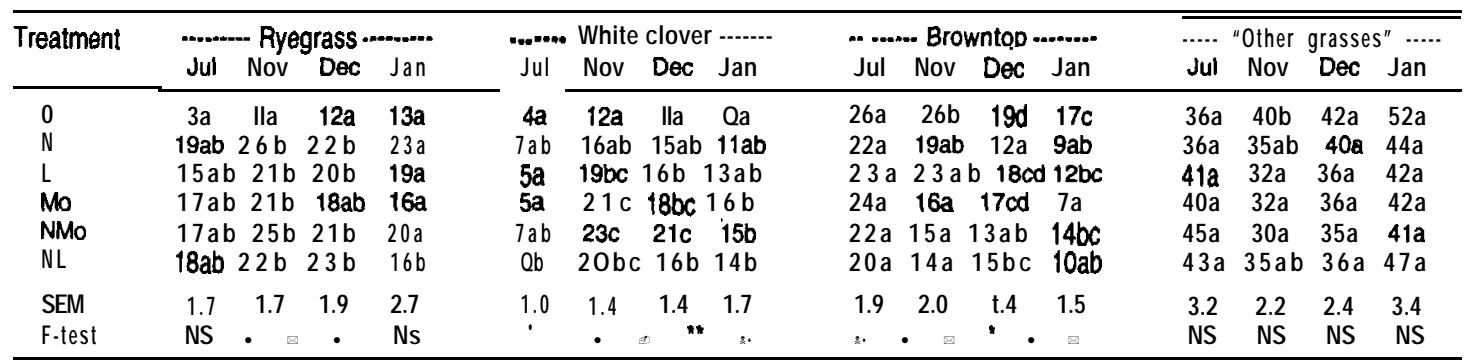

Note: means with the same letter within each column are not significantly different $(P>0.05)$.

*: $P<0.05^{* *}: P<0.01^{* * *}: P<0.001$ NS: not significant

additive and there was no interaction between them for increasing herbage mass accumulation. These were comparable with values reported by Luscombe (1979) of 10-25, Sherlock \& O'Connor (1974) of 24, and Ball et al. (1976) of $14-31 \mathrm{~kg} \mathrm{DM} / \mathrm{kg} \mathrm{N}$ applied. The seasonal differences of $\mathrm{N}$ response efficiency is most likely to be attributable to the variable weather over spring/ summer. Pasture growth was good in summer, requiring more available $\mathrm{N}$, and resulted in a larger $\mathrm{N}$ response efficiency (Table 2). This is in agreement with the suggestion by Ball (1978) that the requirements for $\mathrm{N}$ at high growth rates were proportionately greater than at low growth rates.

The $\mathrm{N}$ application increased the ryegrass content in the sward but the white clover content was little affected (Table 3). In addition, the fact that the $\mathrm{N}$ application decreased the browntop and other low-fertility-tolerant grasses species content in this hill pasture, suggests that pasture species may be critical in determining $\mathrm{N}$ responses in lower fertility pastures. This was supported by some early reports (Luscombe et al. 1981; Ball et al. 1982).

\section{Response to Mo application}

Mo application increased herbage mass on average by $18 \%$ during the period from September to January compared with control treatment (Table 1) but the effect tended to decrease over spring/summer. The effect of Mo application was equivalent to the $\mathrm{N}$ treatment in spring but declined over summer. Mo increased both the white clover and ryegrass content in the hill sward at the expense of browntop (Table 3 ). These responses can be explained by a $17 \%$ increase in available soil $\mathrm{N}$ and a $25 \%$ increase in potential mineralisable $\mathrm{N}$ compared with control (Table 4). Mo deficiency can often be alleviated by liming but the response to lime followed a different pattern to the Mo response, suggesting that this was not the case.
Table 4 The soil nitrogen status of existing mineral N (EMN) and potentially mineralisable $\mathrm{N}(\mathrm{PMN})$ in October $(\mu \mathrm{g}$ $\mathrm{N} / \mathrm{g}$ soil within $0-7.5 \mathrm{~cm}$ soil depth).

\begin{tabular}{lll}
\hline Treatments & EMN & PMN \\
\hline 0 & $0.870 \mathrm{a}$ & $1.325 \mathrm{a}$ \\
$\mathrm{N}$ & $1.136 \mathrm{a}$ & $1.250 \mathrm{a}$ \\
$\mathrm{L}$ & $1.120 \mathrm{ab}$ & $2.263 \mathrm{c}$ \\
fib & $1.015 \mathrm{ab}$ & $1.653 \mathrm{ab}$ \\
NMo & $1.320 \mathrm{~b}$ & $1.338 \mathrm{a}$ \\
NL & $1.263 \mathrm{ab}$ & $2.133 \mathrm{bC}$ \\
SEM & 0.122 & 0.177 \\
F-test & Ns & $\cdot$ \\
\hline
\end{tabular}

\section{Response to liming}

Lime application significantly increased herbage mass from $4 \%$ to $15 \%$ compared with control ( $>>0.05$ ) and the response increased over spring/summer (Table 1). However, the effect of liming was from $7-24 \%$ less than that of $\mathrm{N}$ application. The response to lime was less than that to Mo over spring, but subsequently it was larger than the Mo response. Lime application increased the white clover content (from 25\% to 58\% compared with control) (Table 3), probably owing to the increase in soil $\mathrm{pH}$ and possibly $\mathrm{Mo}$ availability in this hill soil. Liming also increased the rate of soil $\mathrm{N}$ mineralisation; available mineral $\mathrm{N}$ was $29 \%$ and

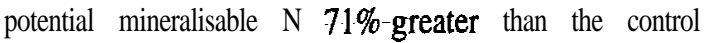
(Table 4). Edmeades et al. (1990) found that the major effect of liming was initially to enhance grass production, presumably by increasing the rate of net soil $\mathrm{N}$ mineralisation. On the other hand, liming increased soil moisture by $1.526 .3 \%$ compared with control (Table 5), which was attributed to the effect of liming on the hill soil structure improvement. This could account for the positive response of herbage mass accumulation to lime application in summer. Jackson \& Gillingham (1985) suggested that lime improved soil moisture relationships by alleviating water repellency of hill soils. 
Table 5 The monthly soil moisture on different treatments (\% by volume)

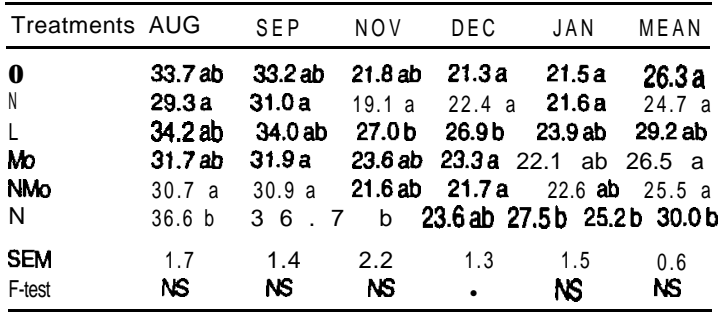

Note; means with the same letter within each column are not significanty differ $(\mathbf{P}>0.05)$

: $P<0.05 *:: P<001 \quad$ * *: $P<0.001$ NS: not significant

\section{Conclusions}

1. The applications of Mo, lime and $\mathrm{N}$ were very effective in this hill pasture owing to the low soil $\mathrm{N}$ availability and Mo deficiency.

2. Mo application increased herbage mass from $0.4 \%$ to $32 \%$ and the effect tended to decrease over the spring/summer. The effect of Mo application was larger than that of liming but less than that of $\mathrm{N}$ alone application. An increase in white clover content in the sward was considered to be the main reason for this response. Mo application has great economic potential for hill farming practice.

3. Liming significantly increased the soil $\mathbf{p H}$ from 0.24 to 0.3 units $/ 2000 \mathrm{~kg}$ lime applied and the soil potential mineralisable $\mathrm{N}$ increased by $71 \%$. Also, liming increased the soil moisture over dry spring/ summer from $11 \%$ to $26 \%$. The result was an increase in herbage mass accumulation from $4.4 \%$ to $15 \%$.

4. $\mathrm{N}$ fertiliser increased herbage mass by from 3 to 41 $\mathrm{kg} \mathbf{D M} / \mathbf{k g ~} \mathrm{N}$ applied, and the response was increased by the addition of lime or Mo.

\section{REFERENCES}

Ball, R.; Inglis, J.A.H.; Mauger, J.H. 1976. Tactical application of fertilizer nitrogen to offset seasonal feed shortage on a heavily-stocked sheep farm in southern Hawke's Bay. Proceedings of the NZ Grassland Association 37: 166-18 1.

Ball, R.; Molloy, L.F.; Ross, D.J. 1978. Influence of fertilizer nitrogen on herbage dry matter and nitrogen yields, and botanical composition of a grazed grassclover pasture. New Zealand journal of agricultural research 21: 47-55.

Ball, R.; Luscombe, P.C.; Grant D.A. 1982. Nitrogen on hill country. pp 133-148 In Nitrogen fertilizers in New Zealand agriculture Lynch, P.B. ed.
During, C. 1962. Liming in New Zealand. New Zealand journal of agriculture 104: $67-73 ; 109-120$.

During, C. 1972. Fertilizer and soils in New Zealand farming. New Zealand Department of Agriculture bulletin No 409. Wellington, Government printer.

During, C.; Jackson, B.L.J.; Dyson, C.B. 1984. Lime effects on hill country 1. Effect of lime and monocalcium phosphate on soil moisture. New Zealand journal of agricultural research 27: 383387.

Edmeades, D.C. 1981. Lime research by the Ministry of Agriculture and Fisheries. New Zealand agricultural science 15: 192-199.

Edmeades, D.C.; O'Connor, M.B.; Toxopeus, M.R.J. 1979. Effect of lime on pasture and animals. Proceeding of Ruakura Farmer's Conference 30: 57-67.

Edmeades, D.C.; Pringle, R.M.; Shannon, P.W.; Mansell, G.P. 1984. Effects of lime on pasture production on soils in the north island of New Zealand. New Zealand journal of agricultural research 27: 371-382.

Edmeades, D.C.; Wheeler, D.M.; Rys, G.; Smith, N. 1990. Effect of pasture composition on lime and phosphorus responses on a dryland soil. Proceedings of the NZ Grassland Association 52: 171-176.

Jackson, B.L.J.; Gillingham, A.G. 1985. Lime soil moisture relationships. pp. 58-60. In Proceedings of a Workshop on Lime in New Zealand, Jackson, B.L.T.; Edmeades, D.C. eds. NZ Ministry of Agriculture and Fisheries, Hamilton, New Zealand.

Luscombe, P.C. 1979. Nitrogen fertilizer responses on hill country pasture. Proceedings of the N Z Grassland Association 41: 155-162.

Luscombe, P.C. 1981. Fertilizer nitrogen response on two hill pastures of different phosphate fertilizer history. New Zealand journal of experimental agriculture 9: 57-61.

Pollock, J.A.; McLaughlin, B. 1986. The soils of Tuapaka Farm, Tuapaka Farm Series Publication No. 3. Massey University, Palmerston North.

Scott, R.S.; Cullen, N.A. 1963. Long term studies of molybdenum applied to pasture. I: The effect of Mo and lime and their interaction. New Zealand journal of agricultural research 6: 538-555.

Sherlock, R.R.; O'Connor, M.B. 1973. The use of nitrogen on hill country. Proceeding of the N Z Grassland Association 35: 52-62.

White, J.G.H. 1990. Hill and high country pasture, pp 307-320, $h$ Pastures: their ecology and management. Langer, R.H.M. ed. Oxford University Press, Auckland. 